\title{
In-vitro Efficacy of Botanical and Selected Bio-Agents in the Management of Fusarial wilts of Tomato (Lycopersicon esculentum L.)
}

\author{
Vinny John*, Sunil Zacharia, Amit Kumar Maurya, Anoop Kumar and Sobita Simon
}

Department of Plant Pathology, Sam Higginbottom University of Agriculture Technology and Sciences, Prayagraj, India

*Corresponding author

\section{A B S T R A C T}

\section{Keywords}

Carbendazim,

Fusarium

oxysporum f. sp.

lycopersici,

Lycopersicon esculentum, Neem

leaf extract,

Pseudomonas

fluorescens,

Trichoderma

harzianum, $T$. viride

Article Info

Accepted:

15 May 2019

Available Online:

10 June 2019

\section{Introduction}

Tomato is a most popular widely grown vegetable in the world. Both the species and its use as a food originated in Mexico, and spread around the world (Nem Pal Singh et.al 2004). Edible fruit, often red in color from the plant (Lycopersicon esculentum) from a member of family solanaceae is mainly cultivated as vegetable. It is a rich source of vitamin C; it also contains minerals like calcium, phosphorus (Linger and Hill 1991). As it is a short duration crop and gives high yield, it is important from economic Point of view and hence are under its cultivation is increasing day by day. Fusarium oxysporum f. sp. lycopersici (FOL) is a highly destructive pathogen of both green house and field grown tomatoes in worm vegetable production areas. The disease caused by this fungus is 
characterized by wilted plants, yellowed leaves and minimal or no crop yield (Asha et al., 2011). Wilt is one of the most economically important disease world-wide (Alexander and Tucker, 1945; Cal et al., 2004; Srinon et al., 2006). Fusarium wilt is soil- borne in nature; it produces two different kinds of conidia which is micro and macro conidia respectively. During unfavorable condition it survives in the form of chlamydospore. The fungus causes vascular wilts by infecting plants through the roots and growing internally through the cortex to the stele (Bowers and Locke 2000). Control of wilt diseases depends mainly on fungicides (Minton 1986). Several fungicides have been used for control of different plant pathogens including Fusarium (Liggit et al., 1997) and the number of effective fungicides with negligible effect on the environment is rare. Fungicides are expensive, can cause environmental pollution and may cause the selection of pathogen resistance (Lumsden and Locke 1989).

\section{Materials and Methods}

The experiment was conducted in the research laboratory in the Department of Plant Pathology, Sam Higginbottom Institute of Agriculture, Technology and Sciences, Deemed to be University, Allahabad (20132014), in-vitro. The infected plant, showing characteristic symptoms of wilt disease (infected plant collected from Plant Pathology Central Research Farm) was cut with healthy portion into small pieces $(2 \mathrm{~mm})$, surface sterilized with 0.1 per-cent mercuric chloride $(\mathrm{Hg} \mathrm{Cl2})$ solution, thrice rinsed in sterilized distilled water and then transferred aseptically on PDA medium, and incubated at $25 \pm 2{ }^{\circ} \mathrm{C}$. After 3 days, a whitish colony growth was observed, from this whitish colony growth, a portion from the periphery having single hyphal tip were separated and transferred to other petri-plate shaving medium to get pure culture and slides were prepared for the identification, which showed the mycelium of the fungus which was both inter and intracellular within the mesophyll and vascular bundle (in xylem) tissues of the root. Macro conidia are usually relatively rare; fusiform mostly 2-3 septate while micro conidia were abundantly produced and are unicellular. The fungus isolated from infected tomato plants was identified as $F$. oxysporum f. sp. lycopersici.

Freshly prepared neem leaves extract i.e,@10\% concentration, were used in each conical flask of $250 \mathrm{ml} ; 90 \mathrm{ml}$ PDA $+10 \mathrm{ml}$ prepared extract were added to it and sterilized.

In dual culture method, $9 \mathrm{~mm}$ width of petri dish of fifteen days old fungal culture were placed on a PDA medium one $\mathrm{cm}$ away from the edge of the plate. $T$. harzianum, $T$. viride and $P$. fluorescens were inoculated at opposite side of each petri-plate with the test pathogen.

In poison food technique, neem leaf extract $10 \%$ and carbendazim $0.1 \%$ with $10 \mathrm{ml}$ of PDA poured in each petriplates.

5 replicates of each treatment and control with normal PDA was incubated at $25 \pm 20$ C. Percent inhibition over control was calculated by the following formula at 7 days of interval-

$$
\mathrm{I}=\frac{(\mathrm{C}-\mathrm{T})}{\mathrm{C}}
$$

Where,

I=Per-cent reduction in growth of test pathogen

$\mathrm{C}=$ Radial growth $(\mathrm{cm})$ in control

$\mathrm{T}=$ Radial growth $(\mathrm{cm})$ in treatment 
Radial growth $(\mathrm{cm})$ at different hours was observed and recorded. Six treatments (including control) were replicated five times. Effect of bio-agents neem leaf extract and fungicide carbendazim (check) against test pathogen $F$. oxysporum $f$. sp. lycopersici, invitro.

\section{Results and Discussion}

To evaluate the efficacy of antagonist and neem leaf extract. Dual culture and poison food technique were respectively adopted in- vitro. The maximum reduction percentage of mycelia growth recorded in treatment $T$. viride which inhibited $(87.44 \%)$ of the colony growth of test pathogen followed by carbendazim which was second most effective growth inhibitor $(87.11 \%), T$. harzianum T2 per-cent inhibition recorded $(80.88 \%)$ and $P$. fluoresens inhibited $(80.77 \%)$ of the radial growth of pathogen, neem leaves extract inhibited $(80.66 \%)$ colony growth of the test pathogen in comparison to control (Table 1 and 2).

Table.1 Effect of Trichodrema spp and P. fluorescens carbendazim and neem leaf extract on growth of $F$. oxysporum lycopersici (L.)

\begin{tabular}{|c|c|c|c|c|c|c|c|c|c|}
\hline & Treatments & 24hrs & 48hrs & $72 \mathrm{hrs}$ & 96hrs & $120 \mathrm{hrs}$ & 144hrs & $168 \mathrm{hrs}$ & $\begin{array}{l}\text { Percent } \\
\text { inhibition } \\
(\%)\end{array}$ \\
\hline T0 & Control & 2.960 & 3.600 & 4.160 & 4.740 & 6.260 & 8.270 & 9.000 & \\
\hline T1 & $\begin{array}{l}\text { Trichoderma } \\
\text { viride }\end{array}$ & $0.230^{b c}$ & $0.260^{\mathrm{b}}$ & $0.810^{\mathrm{ab}}$ & $1.340^{\mathrm{b}}$ & $1.450^{\mathrm{a}}$ & 1.840 & 2.060 & 87.44 \\
\hline $\mathbf{T} 2$ & $\begin{array}{l}\text { Trichoderma } \\
\text { harzianum }\end{array}$ & $0.370^{\mathrm{a}}$ & 0.740 & 1.180 & $2.330^{\mathrm{a}}$ & 0.170 & $1.50^{\mathrm{a}}$ & $2.480^{b}$ & 80.88 \\
\hline T3 & $\begin{array}{l}\text { Pseudomonas } \\
\text { fluoresens }\end{array}$ & $0.810^{\mathrm{bc}}$ & $1.010^{\mathrm{a}}$ & 1.780 & 2.920 & 3.050 & $1.60^{\mathrm{a}}$ & $2.970^{\mathrm{a}}$ & 80.77 \\
\hline T4 & $\begin{array}{ll}\text { neem } & \text { leaf } \\
\text { extract } & \end{array}$ & $0.580^{\mathrm{ab}}$ & $1.480^{\mathrm{a}}$ & $2.280^{\mathrm{a}}$ & $2.030^{\mathrm{a}}$ & 2.480 & $2.730^{\mathrm{a}}$ & $2.630^{\mathrm{ab}}$ & 80.66 \\
\hline T5 & Carbendazim & $0.100^{c}$ & $0.150^{b}$ & $0.640^{\mathrm{b}}$ & $1.390^{b}$ & $1.360^{\mathrm{a}}$ & $2.480^{\mathrm{a}}$ & $2.470^{b}$ & 87.11 \\
\hline & S. Ed. ( $( \pm)$ & 0.416 & 0.112 & 0.096 & 0.088 & 0.084 & 0.037 & 0.085 & \\
\hline & C. D. $(P=0.05)$ & 0.108 & 0.433 & 0.408 & 0.384 & 0.375 & 0.237 & 0.375 & \\
\hline
\end{tabular}

Note: Data are average of five replications. Values followed by same letters in the column are non-significant. 


\section{Pure culture of $F$. oxysporum f. sp. lycopersici}

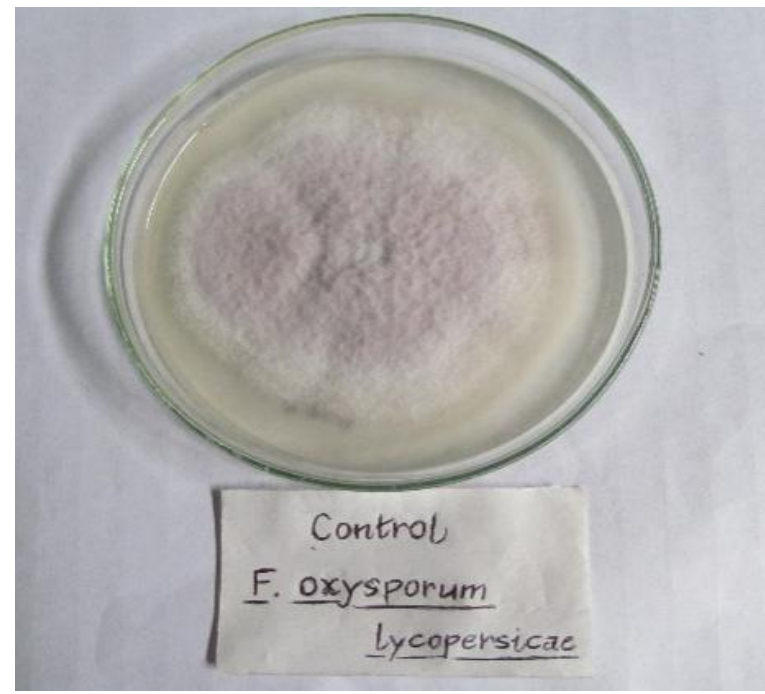

Table.2 Effect of Trichodrema spp and P. fluorescens, carbendazim and neem leaf extract on growth of $F$. oxysporum $\mathrm{f}$. sp. lycopersici

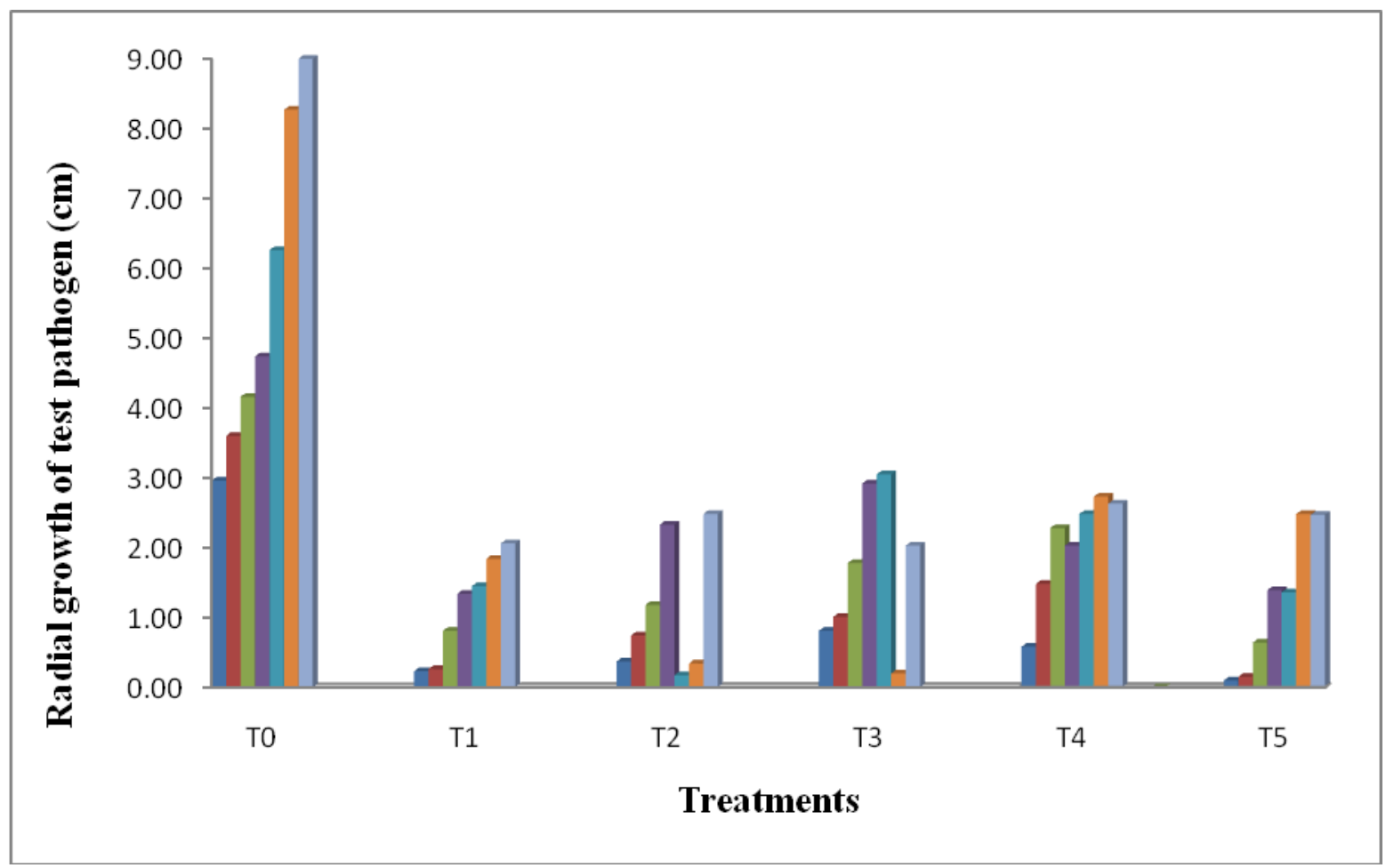

The most effective treatment among all was Trichoderma viride which inhibited the growth of test pathogen completely. The antagonist Trichoderma viride grew very fast than $F$. oxysporum lycopersici and did not allowed the test pathogen to grew on the PDA medium, carbendazim, which was also effective in suppressing the growth of pathogen followed by $T$. harzianum, $P$. flourescens and neem extract. The following 
mentioned data were obtained by recorded continuous observation for seven days, after inoculation of pathogen on media treated with different bio-agents, cardendazim and neem leaves extract compared with control. Similar findings were observed Amini and Sidovich. (2010).

Summary and Conclusions are as follows:

T. viride was the best among all treatments followed by carbendazim, $T$. harzianum, $P$. fluorescens and neem leaf extract in comparison to control. In-vitro trails also found in the findings of Nikam et al., (2007), Sivakumar et al., (2008), Chakraborty et al., (2009)

\section{References}

Abdul Qayoom Rajput, Arain, M. H., Pathan, M. A., Jiskani, M. M. and Lodhi, A. M. Efficacy of different fungicides against Fusrium wilt of cotton caused Fusarium oxysporum f.sp. vasinfecum. Pakistan Journals of Botany, 2006, 38 (3): 875880.

Abogharsai, A., Saeed. M. A., and Buhidma, M. S. Control of Fusarium wilt fungus on tomato plant by plant extracts. Mukhtar University, El-Bida, Libya; (2) Agriculture Minstery, P.O. Box 390, ElBida, Libya.

Agrios, G. N. Plant Pathology. Elsevier Academic Press, New York. 2005, $3^{\text {rd }}$ edition.

Alexander, L. J. and Tucker, C. M. Physiological specialization in the tomato wilt fungus Fusarium oxysporum f.sp. lycopersici. Journal of Agricultural Research, 1945, 70:303313.

Al-Hazmi R. H. M. Effect of neem leaves and seeds extract on the growth of six of the plant disease causing fungi Global advanced research Journal of
Microbiology (ISSN 2315-5116, 2013, 2(5): 089-098.

Amini, J. and Sidovich, D. F. The effect of fungicides on Fusarium oxysporum f. sp. lycopersici associated with Fusarium wilt of tomato. Journal of Plant Protection Research, 2010, 50 (2): 1-2.

Aneja, K. R. Experiments in Microbiology; Plant Pathology and Biotechnology, ( $4^{\text {th }}$ ed. $)$, New age International (P). Ltd. Publishers, New Delhi, 2004, pp, 437450.

Asha, B. B., Chandra, N. S., Udaya, S. A. C., Srinivas, C. and Niranjana, S. R. Biological control of Fusarium oxysporum f.sp. lycopersici causing wilt of tomato Pseudomonas fluorescens. International Journal of Microbiology Research, 2011, 3 (2):79-84.

Barnwal, Maiti, Pandey, M. K. and A. C. Management of tomato wilt caused by Fusarium oxysporum f. sp. lycopersici by using of bio-agents and organic amendments. Indian phytopathology, 2011, 64(2): 194-196.

Bdel-Monaim M. F., Abdel-Gaid M. A., Hanaa, Armanious, A. H. Impact of chemical inducers on vigor, yield, fruit quality and controlling root rot /wilt diseases of tomatoes in New Valley, Egyptians International Research Journal of Microbiology, 2012, 1(9): 366.

Bowers, J. H. and Locke, J. C. Effect of botanical extracts on the population density of Fusarium oxysporum in soil and control of Fusarium wilt in the greenhouse. Plant Disease, 2000, 84:300-305.

Chakraborty, M. R., Chatterjee, N. C., and Quimio, T. H. Integrated management of fusarial wilt of eggplant (Solanum melongena) with soil solarization. Abstracts Micological Aplicada International, 2009, 21 (1): 25-36.

Christopher, D. J., Raj, T.S., Rani, S. U. and 
Kumar, R. U. Role of defense enzymes activity in tomato as induced by Trichoderma virens against Fusarium wilt caused by Fusarium oxysporum $\mathrm{f}$. sp. lycopersici. Journal of Bio pesticides, 2010, 3(1):158-162.

Langer, R. H. M and Hill, G. D Agricultural plants, second edition; Cambridge University 1991, 387- page.

Leslie, J. F. and Summerell, B. A. The Fusarium laboratory manual, Blackwell publishing professional, Hoboken, Journal Plant Protection. 2006, 212.

Liggit, J. Jenkinson, P. and Parry, D. W. The role of saprophytic microflora in the development of Fusarium ear blight of winter wheat caused by Fusarium culmorum. Crop protection, 1997, 16:679-685.

Minton, E. B. Half a century dynamics and control of cotton disease. In: proceedings of Beltwiae cotton conference, National Cotton Council of America, Memphis, TN, USA, 1986, pp 33-35.

Musmade, N., Pillai, T., Thakur, K. Biological and chemical management of tomato wilt caused by Fusarium oxysporum f. sp. lycopersici. Journal of Soils and Crops, 2009, 19(1): 118-121.

Nem Pal Singh; Bhardwaj A.K., Abnish Kumar., and Singh K.M Modern technology on vegetable production, first edition, publication International book distributing co. 2004, pages 84-86.

Nikam, Jagtap, P. S., Sontakke, G. P., and Sontakke, P. L. Management of chick pea wilt caused by Fusarium oxysporum f. sp. ciceri. Journal of Agricultural Research, 2007, 2(12): 692-697.

Reis A., Costa H., Bioteux L. S., and Lopes C. A. First report of fusarium oxysporum f.sp. lycopersici Race 3 on tomato in Brazil. Fitopatologia Brasileira. 2005, 30:426-428.

Sibounnavong, P. Soytong., K. Divina, C. C. and Kalaw, P. S. In-vitro biological activities of Emericella nidulans, a new fungal antagonist, against Fusarium oxysporum f. sp. lycopersici. Journal of Agricultural Technology. 2009, 1:7584.

Singh, D. Role of fungicides and bio-control agents in the management of Fusaril wilt of chili. Journal of Mycology Plant Pathology, 2007, 37(2):60-63.

Singh, T. Chaurasia., D. K. Biological control of tomato wilt. Journal of Eco-friendly Agriculture, 2008, 3 (2): 183-184.

Sivakumar, T., Eswarana, A. and Balabasker, P. Bio-efficacy of antagonists against for the management of Fusarium oxysporum f. sp. lycopersici and Meloidogyne incognita disease complex of tomato under field condition. Plant Archives, 2008, 8 (1): 373-377.

\section{How to cite this article:}

Vinny John, Sunil Zacharia, Amit Kumar Maurya, Anoop Kumar and Sobita Simon. 2019. Invitro Efficacy of Botanical and Selected Bio-Agents in the Management of Fusarial wilts of Tomato (Lycopersicon esculentum L.). Int.J.Curr.Microbiol.App.Sci. 8(06): 1821-1826. doi: https://doi.org/10.20546/ijcmas.2019.806.217 